J. AMER. SOC. HorT. SCI. 115(3):478-481. 1990

\title{
Limitations of Photosynthesis in Lolium perenne after Chilling
}

\author{
J.W. Moon, Jr., D.M. Kopec, E. Fallahi, and C.F. Macino \\ Department of Plant Science, University of Arizona, Tucson, AZ 85721
}

D.C. Slack and K. Jordan

Department of Agricultural Engineering, University of Arizona, Tucson, AZ 85721

Additional index words. perennial ryegrass, $\mathrm{CO}_{2}$ assimilation, carboxylation efficiency, stomatal limitations, nonstomatal limitations

\begin{abstract}
Photosynthesis was reduced by $85 \%$ to $90 \%$ in perennial ryegrass (Lolium perenne $\mathrm{L}$. cv. Derby) following a one-day chilling exposure at $8 \mathrm{C}$ day $\left(450 \mu \mathrm{mol} \cdot \mathrm{s}^{-1} \cdot \mathrm{m}^{-2} \mathrm{PPF}\right)$ and $5 \mathrm{C}$ night. Seven days of recovery at $22 / 17 \mathrm{C}$ day/ night were required for full recovery of photosynthesis. More than $75 \%$ of the limitation in photosynthesis following chilling was due to non-stomatal factors, and reduced initial slopes of $\mathrm{CO}_{2}$ assimilation vs. intercellular $\mathrm{CO}$, indicate that photosynthetic capacity was reduced for 5 days following chilling. Carbon dioxide assimilation at saturating intercellular $\mathrm{CO}_{2}\left(>500 \mu \mathrm{mol} \cdot \mathrm{mol}^{-1}\right)$ was also reduced by chilling, indicating again that stomatal limitations were a minor contributor to the photosynthetic reduction observed under ambient $\mathrm{CO}_{2}$.
\end{abstract}

Many plant species originating in tropical and subtropical climates are classified as thermophilic and show dramatic reductions of growth when exposed to low but above-free, temperatures: These chilling-sensitive plant species commonly incur damage between 0 and 15C (Oquist and Martin, 1986). Chilling sensitivity is not restricted to thermophilic species, as some temperate plant species are also affected by chilling temperature (Bramlage, 1982). The photosynthetic apparatus of many thermophilic plant species is especially sensitive to chilling temperatures, and inhibition of photosynthesis after a chilling exposure may last for several days (Larcher and Bauer, 1981; Bauer et al., 1985; Purcell et al., 1987). Observations suggest that the lower the temperature, the longer the exposure to chilling, and the higher the light intensity during chilling, the greater the damage to photosynthetic capacity (Long et al., 1983; Oquist, 1983; Powles et al., 1983; Krizek et al., 1985; Oquist and Martin, 1986).

Perennial ryegrass is a temperate, cool-season grass used as forage and as a turfgrass. Turf-type perennial ryegrasses are used as year-round turfs in maritime climates and in the midAtlantic region of the eastern United States. It achieves maximum turf performance under environmental conditions ideal for shoot (20 to $25 \mathrm{C}$ ) and root (12 to $15 \mathrm{C})$ growth. Thus, it is productive in only a narrow range of environmental conditions and is sensitive to many environmental stresses, including those from heat, salt, drought, and cold (Turgeon, 1985).

Perennial ryegrass is seeded over bermudagrass turf in the desert southwestern United States to provide green playing surfaces on golf courses during the winter. When used as an overseed turf during November through March, perennial ryegrass is often subjected to chilling temperatures. Dramatic decreases in calculated canopy conductance to water vapor following chilling exposures have been measured during attempts to use energy-balance approaches to schedule irrigation of ryegrass turf (Slack and Kopec, 1988). Successful energy-balance approaches to scheduling irrigation depend on a correlation between canopy temperature and the water status of the plants.

Received for publication 17 Jan. 1989. This research was supported in part by a grant from the Arizona Water Resources Commission. The cost of publishing this paper was defrayed in part by the payment of page charges. Under postal regulations. this paper therefore must be hereby marked advertisement solely to indicate this fact.
As water stress develops, canopy moisture conductance decreases, and canopy temperature rises. Under severe water stress, canopy temperatures of turf can be elevated above air temperatures. Canopy temperatures of well-irrigated ryegrass measured under warm midday conditions (>20C) remained below air temperature, whereas temperature of water-stressed ryegrass was 4 to 6C above air temperature (Slack and Kopec, 1988). Canopy temperatures of 4 to $6 \mathrm{C}$ above air temperature and reduced canopy conductance have been measured in both well-irrigated and water-stressed ryegrass following cool days in the chilling range $(0$ to $15 \mathrm{C})$ and under clear days also in the chilling range, but with intense radiation (1500 to $2000 \mu \mathrm{mol} \cdot \mathrm{s}^{-1} \cdot \mathrm{m}^{-2} \mathrm{PPF}$ ) (Slack and Kopec, 1988), which are conditions leading to enhanced photosynthetic impairment in chilling-sensitive species. In summary, there is considerable observational evidence that susceptibility to chilling injury may contribute to the inability of energybalance techniques to determine the water status of "perennial ryegrass during the winter season in the southwestern United States. This chilling response in ryegrass could be due to: 1) damage that directly reduces stomatal conductance; 2) direct impairment of the photosynthetic apparatus, which would secondarily raise canopy temperature when stomatal conductance is reduced by accumulation of intercellular $\mathrm{CO}$; or 3 ) a combination of both stomatal and non-stomatal factors.

Photosynthetic inhibition due to chilling exposure has been reported in Bermudagrass (Cynodon dactylon L.) (White and Schmidt, 1988), and, in a summer annual ryegrass (Lolium temulentum), growth is reduced under chilling temperatures but photosynthetic capacity is not damaged (Pollock et al., 1983). Virtually nothing is known about the effects of chilling temperatures on the photosynthetic capacity of perennial ryegrass. A goal of the present study was to determine the extent and duration of reduction in net photosynthesis of perennial ryegrass following a chilling exposure, and to partition any photosynthetic inhibition into proportions due to stomatal and non-stomatal factors.

\section{Materials and Methods}

Plant material. 'Derby' perennial ryegrass was seeded at 50 $\mathrm{g} \cdot \mathrm{m}^{-2}$ in 0.35 -liter Styrofoam pots containing 1 shredded sphagnum peat : 1 perlite, $(\mathrm{v} / \mathrm{v})$. Pots were kept for 10 days in a germinator at a constant $18 \mathrm{C}$ and under a 12-hr photoperiod. After germination, plants were grown outdoors for 12 weeks in 
a shade house providing $20 \%$ reduction in solar radiation. Blades were clipped twice weekly at a height of $5 \mathrm{~cm}$ and fertilized with $350 \mathrm{~N}-100 \mathrm{P}-200 \mathrm{~K}$ (ppm) or with one-half-strength modified Hoagland's solution every 3 weeks to provide balanced nutrition.

Plants then were hardened for $72 \mathrm{hr}$ in a growth chamber under a 12-hr photoperiod $\left(450 \mu \mathrm{mol} \cdot \mathrm{s}^{-1} \cdot \mathrm{m}^{-2} \mathrm{PPF}\right)$ and at $22 /$ 17C day/night. Plants were further hardened under 12-hr photoperiod at $17 / 14 \mathrm{C}$ day/night for $72 \mathrm{hr}$, and then were chilled for $24 \mathrm{hr}$ at $8 / 5 \mathrm{C}$ day/night.

Gas exchange response to increasing $\mathrm{CO}_{2}$ was measured on five plants immediately after chilling and on five control plants that were kept in the greenhouse at 25/18C day/night. All remaining chilled plants were kept in the growth chamber at 22/ 17C day/night and allowed to recover for 3, 5, or 7 days. Five separate plants were sampled for gas exchange at 3, 5, or 7 days of recovery and compared to control plants. Data were analyzed as a completely randomized design with each plant being a replication $(n=5)$. Dunnett's one-sided $t$ test was used to compare the means from each chilling treatment $(0,3,5$, or 7 days of recovery) to those of controls.

Gas exchange. Gas exchange measurements were made using an open system and temperature-controlled glass cuvette (Perchorowicz et al., 1981). Oxygen, $\mathrm{N}_{2}$, and $\mathrm{CO}_{2}$ were mixed manually using multiple valves, and flow rates into the mixing chamber were measured with mass flow meters (Hastings Models ST 2663 and ST 2664, Hampton, Va.). Response of $\mathrm{CO}_{2}$ assimilation (A) to increasing $\mathrm{CO}_{2}$ was monitored by measuring $\mathrm{CO}_{2}$ gas exchange in step increments from low $(<100$ $\left.\mu \mathrm{mol} \cdot \mathrm{mol}^{-1}\right)$ to high $\mathrm{CO}_{2}\left(1000 \mu \mathrm{mol} \cdot \mathrm{mol}^{-1}\right)$. The reference, sample, and the $\mathrm{CO}_{2}$ differential concentrations between the inlet and outlet gas from the cuvette were measured with an infrared gas analyzer (ADC Model LCA-2, Hoddesdon, Herts, U.K.). Flow rate into the glass cuvette was controlled at 3 liter $\cdot \mathrm{min}^{-1}$, and the air temperature inside the water-cooled cuvette was controlled throughout at $25 \pm 0.5 \mathrm{C}$. Air and leaf temperatures were monitored using thin wire thermocouples. Vapor pressure deficit (VPD) was maintained at 1.5 to $2.0 \mathrm{kPa}$ by saturating the gas stream in a temperature-controlled water bath, and then drying part of the air stream with silica gel. Vapor pressures of the inlet and outlet gases were measured with dew point hygrometers (EG \& G Model 911). Light supplied by a 1000-W metal halide lamp was filtered through $8 \mathrm{~cm}$ of water and neutral density screens. The irradiance level was measured with a quantum sensor (LI-180; LI-COR, Lincoln; Neb.) at the top of the blades and was maintained at a PPF between 1400 and $1600 \mu \mathrm{mol} \cdot \mathrm{s}^{-1} \cdot \mathrm{m}^{-2}$. Calculation of $\mathrm{CO}_{2}$ assimilation, transpiration, stomatal conductance, and intercellular $\mathrm{CO}_{2}(\mathrm{~A}, \mathrm{E}$, $\mathrm{g}_{\mathrm{s}}^{\prime}$, and $\mathrm{C}_{\mathrm{i}}$, respectively) was made using standard equations (Moon and Flore, 1986).

Data analysis. A logarithmic curve was fitted to the data for $\mathrm{CO}_{2}$ assimilation (A) vs. intercellular $\mathrm{CO}_{2}\left(\mathrm{C}_{\mathrm{i}}\right)$, and from this regression equation stomatal limitations were calculated from the method described by Farquhar and Sharkey (1982). Briefly, the method for calculation of stomatal limitations is: 1) A is calculated at the normal atmospheric $\mathrm{CO}_{2}$ concentration of 365 $\mu \mathrm{mol} \cdot \mathrm{mol}^{-1}$; 2) $\mathrm{CO}_{2}$ assimilation at infinite diffusion $\left(\mathrm{A}_{\mathrm{o}}\right)$ is interpolated from the response curve at $\mathrm{C}_{\mathrm{i}}=365 \mu \mathrm{mol} \cdot \mathrm{mol}^{-1}$; $3)$ the relative stomatal limitations are then calculated from the equation $1=\left(A_{0}-A\right) / A_{o} \times 100$. Stomatal limitation (1) is the proportionate decrease in $\mathrm{A}$ that may be attributed to the stomata and other gas phase limitations. Carboxylation efficiency $\left(\mathrm{g}_{\mathrm{m}}^{\prime}\right)$ was determined from linear regression using the linear portion of the $\mathrm{A} / \mathrm{C}_{\mathrm{i}}$ curve (0 to $250 \mu \mathrm{mol} \mathrm{CO}_{2} / \mathrm{mol}$ ). Estimates of carboxylation efficiency $\left(\mathrm{g}_{\mathrm{m}}^{\prime}\right)$ provide a means of assessing the non-stomatal process limiting $\mathrm{CO} 2$ assimilation following a change in environment, e.g., imposition of water or temperature stress. Carbon dioxide assimilation at saturating $\mathrm{CO}_{2}$ levels $\left(\mathrm{A}_{\max }\right)\left(\mathrm{C}_{\mathrm{i}}>500 \mu \mathrm{mol} \cdot \mathrm{mol}^{-1}\right)$ was calculated from the plateau phase of the $A / C_{i}$ curves. Reductions in $A_{\max }$ following an environmental stress arc indications of non-stomatal limitation of A due to damage to photosynthetic electron transport and thereby regeneration of the substrate RuBP.

\section{Results}

Chilling perennial ryegrass at $8 \mathrm{C}$ day $\left(450 \mu \mathrm{mol} \cdot \mathrm{s}^{-1} \cdot \mathrm{m}^{-2}\right.$ PPF) and 5C night temperatures reduced A by $85 \%$ (Table 1, Fig. 1). Similar large reductions (80\% to $90 \%$ ) were observed in transpiration $(\mathrm{E})$, carboxylation efficiency $\left(\mathrm{g}_{\mathrm{m}}^{\prime}\right)$, and stomatal conductance $\left(\mathrm{g}_{\mathrm{s}}^{\prime}\right)$. Most of the reduction in A was due to nonstomatal factors, since stomatal limitation in chilled plants ranged from $18 \%$ to $26 \%$ (Table 1). The smallest reduction in A due to stomatal limitation $(18 \%)$ corresponded to the lowest rate of A (1.59 at Day 0), whereas the highest stomatal limitation (29\%) was observed in control plants (Table 1). Stomatal conductance was also reduced by chilling $(80 \%)$, but recovered much faster than did A. Carbon dioxide assimilation required 7 days for full recovery from chilling (Table 1, Fig. 1), whereas stomatal conductance showed significant recovery in 3 days, not significantly different from controls (Table 1). Linear regression of A vs. $\mathrm{g}_{\mathrm{s}}^{\prime}$ was highly correlated (Fig. 2), and might suggest that $\mathrm{g}_{\mathrm{s}}^{\prime}$ is a primary cause of the low A. However, calculated stomatal limitations at ambient $\mathrm{CO}_{2}$ were low (Table 1), and $\mathrm{CO}_{2}$ assimilation at saturating $\mathrm{CO}_{2}\left(\mathrm{~A}_{\max }\right)$ was reduced $85 \%$ to $90 \%$ by chilling exposure (Table 1 ). The recovery of $A_{\max }$, like the recovery of $A$, required 7 days. Carboxylation efficiency $\left(g_{m}^{\prime}\right)$, which is a measure of photosynthetic capacity, was highly correlated with $\mathrm{A}_{\max }$ (Fig. 2) and also tended to follow the recovery of $\mathrm{A}$ and $\mathrm{A}_{\max }$.

\section{Discussion}

The good correlation often reported between chilling-induced decreases in $\mathrm{E}$ and $\mathrm{A}$ has been taken to indicate that there is a causal relationship between chilling-induced stomatal closure and reductions in A (Pasternak and Wilson, 1972; Crookston et al., 1974; Kishitani and Tsunoda, 1974). This was not the case in perennial ryegrass, as non-stomatal limitations of $\mathrm{A}$ ranged from $75 \%$ to $80 \%$, and $\mathrm{CO}_{2}$ assimilation at saturating $\mathrm{CO}_{2}$ levels $\left(\mathrm{A}_{\max }\right)$ could not compensate for the reduction caused by chilling. If the limitations due to chilling were mostly stomatal, then $A_{\max }$ should not have been affected greatly. Similar reductions $A_{\max }$ and non-stomatal limitations to $\mathrm{A}$ following chilling also have been observed in tomato (Martin et al., 1981), tea (Aoki, 1986), corn (Long et al., 1983), and coffee (Bauer et al., 1985).

Wilting and low leaf-water potentials have been measured in some plants after chilling stress (Vigh et al., 1981; Mustardy et al., 1982; Eamus et al., 1983; Purcell et al., 1987). Such chilling-induced water stress is more pronounced when the chilling exposure is given under high light intensity and large leafto-air vapor pressure deficits. The leaf-water status deteriorates in many cases during chilling exposure, due to comparatively high transpiration rates resulting from stomata closing incompletely at first, combined with a decreased hydraulic conductivity through root plasma membranes under low temperature (Oquist 
Table 1. Effects of 1 day of chilling (Day 0) and for up to 7 days of recovery under warm (22/17C day/night) conditions on the gas exchange characteristics of 'Derby' ryegrass.,

\begin{tabular}{|c|c|c|c|c|c|c|}
\hline $\begin{array}{c}\text { Chilling } \\
\text { test } \\
\text { interval } \\
\text { (days) }\end{array}$ & $\left(\mu \mathrm{mol} \mathrm{CO} / \mathrm{Am}^{2}\right.$ per sec $)$ & $\stackrel{\mathrm{A}}{\mathrm{A}}$ & $\begin{array}{c}\mathbf{g}^{\prime}{ }_{\mathbf{m}} \\
\left(\mathrm{mmol}^{-1} \cdot \mathrm{s}^{-1} \cdot \mathrm{m}^{-2}\right)\end{array}$ & $\underset{\left(\mathrm{mmol} \cdot \mathrm{s}^{-1} \cdot \mathrm{m}^{-2}\right)}{\mathrm{E}}$ & $\left(\mathrm{mmol} \mathrm{CO} / \mathrm{m}^{2}\right.$ per sec) & $\begin{array}{l}1 \\
\text { (\% reduction) }\end{array}$ \\
\hline $\begin{array}{c}\text { No chilling } \\
7 \\
5 \\
3 \\
0\end{array}$ & $\begin{array}{c}18.20 \\
18.96^{\mathrm{NS}} \\
13.28^{* *} \\
7.82^{* *} \\
2.64^{* * *}\end{array}$ & $\begin{array}{c}10.61 \\
11.98^{\mathrm{Ns}} \\
8.70^{*} \\
4.61^{* . *} \\
1.59^{* *}\end{array}$ & $\begin{array}{l}77.6 \\
59.48^{\text {Ns }} \\
57.8^{\text {Ns }} \\
22.3^{* *} \\
7.7^{* *}\end{array}$ & $\begin{array}{l}2.87 \\
2.61^{\text {NS }} \\
2.13^{* *} \\
1.66^{* *} \\
0.52^{* *}\end{array}$ & $\begin{array}{l}75.7 \\
89.5^{\text {Ns }} \\
73.0^{\text {Ns }} \\
61.3^{\text {Ns }} \\
18.6^{* *}\end{array}$ & $\begin{array}{l}29.2 \\
26.2^{\text {NS }} \\
23.6^{*} \\
18.9^{* *} \\
17.8^{* *}\end{array}$ \\
\hline
\end{tabular}

${ }^{\mathrm{x}}$ Carbon dioxide assimilation at saturating intercellular $\mathrm{CO}_{2}>500 \mu \mathrm{mol} \cdot \mathrm{mol}^{-1}\left(\mathrm{~A}_{\max }\right), \mathrm{CO}_{2}$ assimilation $(\mathrm{A})$, mesophyll conductance $\left(\mathrm{g}_{\mathrm{m}}^{\prime}\right)$, transpiration (E), and stomatal conductance to $\mathrm{CO}_{2}\left(\mathrm{~g}_{\mathrm{s}}^{\prime}\right)$ were measured at 24 to $26 \mathrm{C}, 365 \mu \mathrm{mol} \cdot \mathrm{mol}^{-1} \mathrm{CO}_{2}$ and 1400 to $1600 \mu \mathrm{mol} \cdot \mathrm{s}^{-9} \cdot \mathrm{m}^{-2}$ PPF. Percent stomatal reduction (1) was calculated at $365 \mu \mathrm{mol} \cdot \mathrm{mol}^{-1} \mathrm{CO}_{2}$ from the equation $1=\left(\mathrm{A}_{\mathrm{o}}-\mathrm{A}\right) / \mathrm{A}_{\mathrm{o}} \times 100$, where $\mathrm{A}_{\mathrm{o}}$ is the photosynthetic rate to be expected when intercellular $\mathrm{CO}_{2}\left(\mathrm{C}_{\mathrm{i}}\right)$ equals ambient $\mathrm{CO}_{2}\left(\mathrm{C}_{\mathrm{a}}\right)$.

All treatment means $(n=5)$ are compared to controls.

Nonsignificant and significant difference from control at $P=0.05$ and 0.01 , respectively, using Dunnett's one-sided $t$ test.

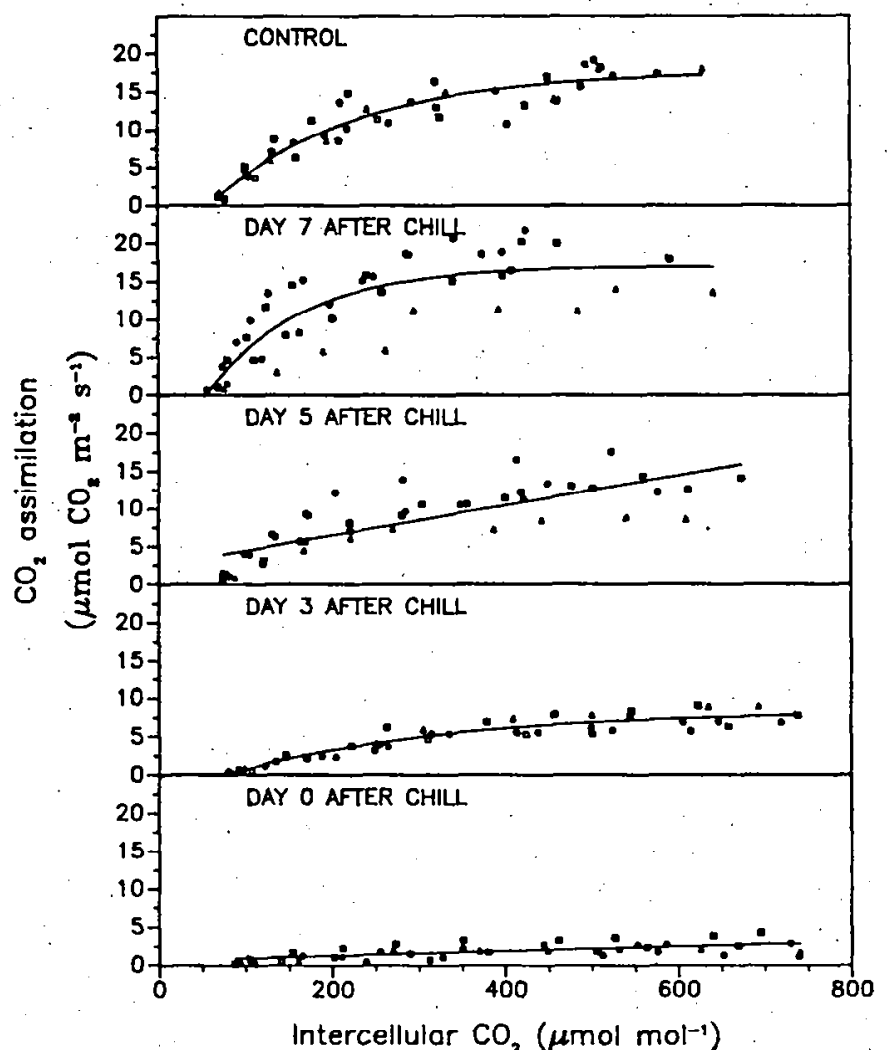

Fig. 1. Effects of intercellular $\mathrm{CO}_{2}$ on $\mathrm{CO}_{2}$ assimilation in perennial ryegrass. Plants were not chilled (Control), chilled at $8 / 5 \mathrm{C}$ day/night with no recovery (Day 0), or chilled with a recovery of 3 (Day 3), 5 (Day 5). or 7 (Day 7) days. Measurements were made at leaf-toair vapor pressure deficits of 1.5 and $2.0 \mathrm{kPa}$, leaves at 24 and $26 \mathrm{C}$, and light intensities of 1400 and $1600 \mu \mathrm{mol} \cdot \mathrm{s}^{-1} \cdot \mathrm{m}^{-2} \mathrm{PPF}$. Different symbols represent different plants $(n=5)$ and lines are the best-fit regressions to the data.

and Martin, 1986). Stomata remain partially closed subsequent to chilling exposure due to certain events not related to water stress. However, when chilling was applied in a water vaporsaturated environment to prevent a drop in leaf water potentials, net photosynthesis was still inhibited even under saturating $\mathrm{CO}_{2}$, which indicates that the primary damage is non-stomatal (Martin et al., 1981). The major cause of reduced $g_{s}^{\prime}$ may be increased $\mathrm{C}_{\mathrm{i}}$ brought about by a direct impairment of the photosynthetic

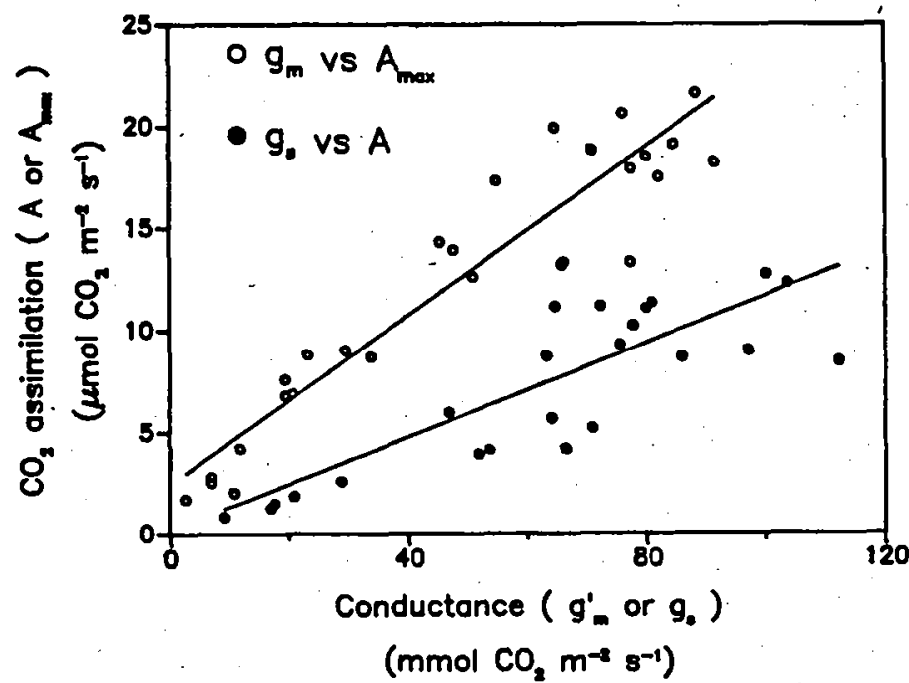

Fig. 2. Linear regression of $\mathrm{CO}_{2}$ assimilation (A) vs. stomatal conductance $\left(\mathrm{g}^{\prime}\right)$, and maximum $\mathrm{CO}_{2}$ assimilation $\left(A_{\max }\right)$ vs. carboxylation efficiency $\left(g^{\prime}\right)$. Gas exchange conditions were as described in Fig. 1, except that the $\mathrm{CO}_{2}$ concentration for measurement of $\mathrm{A}$ was $365 \mu \mathrm{mol} \cdot \mathrm{mol}^{-1}$, whereas that for $A_{\max }$ was $>1000 \mu \mathrm{mol} \cdot \mathrm{mol}^{-1}$ $(C>500)$. Data were pooled for chilled plants, control plants, and plants chilled and given 3,5 , or 7 days of recovery.

apparatus. If reduced $\mathrm{g}_{\mathrm{s}}$, were a direct effect, $\mathrm{C}_{\mathrm{i}}$ should be reduced, and this is not the case in Xanthium (Drake and Raschke, 1974), where stomata are sensitized to $\mathrm{CO}_{2}$ by the chilling stress. Clearly, if water stress develops under a chilling episode, it will synergistically contribute to the reduction in g',, but reduced g's can only account for a minor portion (20\% to $35 \%)$ of the reduction in photosynthetic capacity following chilling (Oquist and Martin, 1986). Neither reduced $\mathrm{g}_{\mathrm{s}}^{\prime}$ nor low leaf-water potentials are necessary for reduced A following chilling, and therefore neither is a required primary factor in the chilling injury to A. Here, VPDs of $<0.25 \mathrm{kPa}$ were maintained in the growth chamber, but leaf water potentials were not measured. No signs of water stress were observed, but even if water stress occurred, it could only account for a small portion of the observed reduction in $\mathrm{A}$.

Complete recovery of photosynthetic capacity often lags behind the recovery of $\mathrm{g}_{\mathrm{s}}^{\prime}$ (Bauer et al., 1985; Oquist and Martin, 1986; Purcell et al., 1987). When chilling was applied in the dark to tomato, $\mathrm{g}_{\mathrm{s}}^{\prime}$ recovered earlier than net photosynthesis 
(Martin et al., 1981). Stomatal conductance following chilling in perennial ryegrass showed substantial recovery within 3 days and complete recovery in 5 days $(P=0.05)$, whereas recoveries of $\mathrm{A}$ and $\mathrm{A}_{\max }$ took 7 days and recovery of $\mathrm{g}_{\mathrm{m}}^{\prime}$ took 5 days. This lag in recovery of photosynthetic capacity again leads us to suggest that the primary damage to perennial ryegrass following chilling is due to non-stomatal factors. Further evidence of non-stomatal involvement was obtained from the reduced initial slopes of A vs. $C_{i}$ curves following chilling, which were observed in this study (Fig. 1) and have been reported for other chilling-sensitive species (Bauer et al., 1985; Aoki, 1986). This response is different from that reported with corn (Long et al., 1983), where initial slopes of $\mathrm{A} / \mathrm{C}_{\mathrm{i}}$ curves are not affected but $\mathrm{A}_{\max }$ is reduced due to a reduction in the regeneration of RuBP and amount of the carboxylase following chilling.

Recent studies (Wise and Naylor, 1987) with cucumber and peas indicate that high light-enhanced $\left(1000 \mu \mathrm{mol} \cdot \mathrm{s}^{-1} \cdot \mathrm{m}^{-2} \mathrm{PPF}\right)$ chilling injury to the photosynthetic apparatus is related to lipid destruction by superoxide anion radicals. Atrazine, an electron transport system inhibitor, reduced the photodestruction of lipids in chilling-sensitive cucumber, whereas chilling-resistant peas only showed lipid damage when treated with the herbicide paraquat, a known enhancer of $\mathrm{O}_{2}$ production. Chilling-tolerant species may have a mechanism for removal of toxic oxygen radicals that may either be missing or reduced in chilling-sensitive plants.

From November through March, the period of overseeding of turf with perennial ryegrass in the desert southwest, night temperatures are frequently $<5 \mathrm{C}$ and there are occasional radiation frosts followed by cold sunny mornings (1500 to 2000 $\left.\mu \mathrm{mol} \cdot \mathrm{s}^{-1} \cdot \mathrm{m}^{-2} \mathrm{PPF}\right)$ in which leaf blades could experience the low temperatures and high PPF shown to produce the chillinginduced reduction in photosynthetic capacity observed here in controlled environments and reported for other grasses (Long et al., 1983). Field measurements of turf canopy temperatures that were 4 to $6 \mathrm{C}$ above air temperature when measured during the winter, (Slack and Kopec, 1988) lead us to suggest that the photosynthetic capacity of perennial ryegrass is reduced by chilling and that pre-conditioning at lower growth temperature does not offer significant protection. We further suggest that the winter chilling damage to perennial ryegrass is primarily due to nonstomatal factors reducing $\mathrm{g}_{\mathrm{s}}^{\prime}$ and producing elevated leaf temperatures in the absence of water stress.

\section{Literature Cited}

Aoki, S. 1986. Site of cold-induced depression of photosynthesis in overwintering tea leaves. Jpn. J. Crop Sci. 55:489-495.

Bauer, H., R. Wierer, W.H. Hatheway, and W. Larcher. 1985. Photosynthesis of Coffea arabica after chilling. Physiol. Plant. 64:449 454.

Bramlage, W.J. 1982. Chilling injury of crops of temperate origin. HortScience 17:165-168.

Crookston, R.K., J. O'Toole, R. Lee, J.L. Ozbun, and D.H. Wallace. 1974. Photosynthetic depression in beans after exposure to cold for one night. Crop Sci. 14:457-464.

Drake, B. and K. Raschke. 1974. Prechilling of Xanthium strumarium L. reduces net photosynthesis and, independently, stomatal conductance, while sensitizing the stomata to $\mathrm{CO}_{2}$. Plant Physiol. 53:808812

Eamus, D., R. Fenton, and J.M. Wilson. 1983. Stomatal behavior and water relations of chilled Phaseolus vulgaris L. and Pisum sativum L. J. Expt. Bot. 34:434-441.
Farquhar, G.D. and T.D. Sharkey. 1982. Stomatal conductance and photosynthesis. Annu. Rev. Plant Physiol. 33:317-345.

Kishitani, S., and S. Tsunoda. 1974. Effect of low and high temperature pretreatment on leaf photosynthesis and transpiration in cultivars of Oryza sativa. Photosynthetica 8:161-167.

Krizek, D.T., P. Semeniuk, H.E. Moline, R.M. Mirecki, and J.A. Abbott. 1985. Chilling injury in coleus as influenced by photosynthetically active radiation, temperature and abscisic acid pretreatment. I. Morphological and physiological responses. Plant Cell \& Environ. 8:135-142.

Larcher, W., and H. Bauer. 1981. Ecological significance of resistance to low temperature, p. 403-437. In: A. Pirson and M.H. Zimmermann (eds.). Encyclopedia of plant physiology. New series, vol. 12A. Springer-Verlag, Berlin.

Long, S.P., T.M. East, and N.R. Baker. 1983. Chilling damage to photosynthesis in young Zea mays. I. Effects of light and temperature variation on photosynthetic $\mathrm{CO}_{2}$ assimilation. J. Expt. Bot. 34:177-188.

Martin, B., D.R. Ort, and J.S. Boyer. 1981. Impairment of photosynthesis by chilling-temperatures in tomato. Plant Physiol. 68:329334.

Moon, J.W. and J.A. Flore. 1986. A BASIC computer program for calculation of photosynthesis, stomatal conductance, and related parameters in an open gas exchange system. Photosyn. Res. 7:269279.

Mustardy, L.A., T.T. Vu, and A. Faludi-Daniel. 1982. Stomatal response and photosynthetic capacity of maize leaves at low temperature, a study of varietal differences in chilling sensitivity. Physiol. Plant. 55:31-34.

Oquist, G. and B. Martin. 1986. Cold climates, p. 237-293. In: N.R. Baker and S.P. Long (eds.). Photosynthesis in contrasting environments. vol. 7. Elsevier, Amsterdam.

Oquist, G. 1983. Effects of low temperature on photosynthesis. Plant Cell \& Environ. 6:281-300.

Pasternak, D., and G.L. Wilson. 1972. After effects of night temperatures on stomatal behavior and photosynthesis of Sorghum. New Phytol. 71:683-689.

Perchorowicz, J.T., D.A. Raynes, and R.G. Jensen. 1981. Light limitation of photosynthesis and activation of ribulose bisphophate carboxylase in wheat seedlings. Proc. Natl. Acad. Sci. USA 78:29852989.

Pollock, P.J., E.J. Lloyd, J.L. Stoddart, and H. Thomas. 1983. Growth, photosynthesis and assimilate partitioning in Lolium temulentum exposed to chilling temperatures. Physiol. Plant. 59:257-262.

Powles, S.B., J.A. Berry, and O. Buorkman. 1983. Interaction between light and chilling temperature on the inhibition of photosynthesis in chilling sensitive plants. Plant Cell \& Environ. 6:117-123.

Purcell, L.C., D.A. Ashley, and H.R. Boerma. 1987. Effects of chilling on photosynthetic capacity and leaf carbohydrate and nitrogen status of soybean. Crop Sci. 27:90-95.

Slack, D.C., and D.M. Kopec. 1988. Effects of non-wafer stressed stomatal control mechanisms on the crop water stress index of ryegrass turf. Paper no. PR88-104. Proc. Amer. Soc. Agr. Eng., 2526 Mar. 1988, Ontario, Calif.

Turgeon, A.J. 1985. Turfgrass science. Reston, New York.

Vigh, L., I. Horvath, T. Farkas, L.A. Mustardy, and A. Faludi-Danies. 1981. Stomatal behavior and cuticular properties of maize leaves of different chilling-resistance during cold treatment. Physiol. Plant. 51:287-290.

White, R.H. and R.E. Schmidt. 1988. Carbon dioxide exchange of 'Tifgreen' bermudagrass exposed to chilling temperatures as influenced by iron and BA. J. Amer. Soc. Hort. Sci. 113:423-426.

Wise, R.R., and W.W. Naylor. 1987. Chilling-enhanced photooxidation of the peroxidative destruction of lipids during chilling injury to photosynthesis and ultrastructure. Plant Physiol. 83:272-277. 